\title{
Induction of L1 mRNA in PC12 Cells by NGF Is Modulated by Cell- Cell Contact and Does Not Require the High-Affinity NGF Receptor
}

\author{
Kouichi Itoh, ${ }^{1}$ Robert Brackenbury, ${ }^{2}$ and Richard A. Akesona \\ 'Children's Hospital Research Foundation, Division of Basic Science Research, Cincinnati, Ohio 45229-3039 and \\ ${ }^{2}$ Department of Cell Biology, Neurobiology and Anatomy, University of Cincinnati, College of Medicine, Cincinnati, \\ Ohio 45267-0521
}

\begin{abstract}
We examined the effects of nerve growth factor (NGF) and cell-cell contact on expression of the neural cell adhesion molecule L1 in PC12 cells. After 7 d exposure to NGF, but not after exposure to EGF, FGF, TGF $\beta$, or dibutyryl cAMP (dbcAMP), L1 mRNA levels increased fourfold. This increase was not blocked by K252a, an inhibitor of the high-affinity NGF receptor, although neurite extension was completely inhibited. L1 mRNA levels also increased in NGF-treated mutant PC12 cells (PC12nnr5) that lack the high-affinity NGF receptor. The effect of NGF on L1 mRNA was greatest in cells cultured at high density, but its effect on cells cultured at low density was augmented by antibody to L1 (to mimic L1 homophilic binding). Various extracellular matrix components had no differential effects on L1 mRNA levels in either the presence or absence of NGF. Together, these findings suggest that NGF regulates $L 1$ expression by a mechanism that is independent of the highaffinity NGF receptor and that this regulation is modulated by cell-cell contact but not by cell-extracellular matrix interactions.
\end{abstract}

[Key words: neural cell adhesion molecule L1, PC12 cells, mRNA, differentiation, NGF, culture, K252a, cell-cell adhesion]

Neuronal gene programming is influenced by extracellular stimuli, including soluble factors and contacts with other cells or with extracellular matrix, which then act through intracellular signals including phosphorylation and second-messenger generation. Nerve growth factor (NGF) is one extracellular stimulus that plays essential roles in the development of both the CNS and PNS (Levi-Montaltini, 1987). Two receptors that bind NGF have been characterized: a high-affinity receptor, gp $140^{r k}$, the product of the proto-oncogene trk (Kaplan et al., 1991a,b; Klein et al., 1991), and a low-affinity receptor, p75 1986; Radeke et al., 1987). In general, effects of NGF, which include survival and morphological differentiation of peripheral neurons, including sensory and sympathetic neurons (Levi-Mon-

Received May 20, 1994; revised Sept. 9, 1994; accepted Oct. 6, 1991.

We are grateful to Dr. Aoshung Chen for useful advice for Northern blot analysis, Roberta Shew for help with production of L1 cDNA probes and antibody to L1, and Ms. Shirley Arnold for assistance. K.I. was supported by a CHMC Trustees Fellowship. This study was supported by NIH Grant HD 21065.

Correspondence should be addressed to Kouichi Itoh, Ph.D., Laboratory of Developmental Neurobiology, NICHD, NIH, Building 49, Room 5A38, Bethesda, MD 20892.

a Deceased. Dr. Itoh dedicates this article to the memory of Dr. R. A. Akeson. Copyright (C) 1995 Society for Neuroscience $0270-6474 / 95 / 152504-09 \$ 05.00 / 0$ taltini, 1987), and differentiation of the rat pheochromocytoma (PC12) cell line (Greene and Tischler, 1976) are mediated by interactions with gp140 ${ }^{\text {rk }}$ (Loeb et al., 1991; Hempstead et al., 1992).

One activity of NGF is its ability to increase polypeptide levels of the neural cell adhesion molecules NCAM and L1 in PC12 cells (Doherty et al., 1987, 1988; Mann et al., 1989). In the present study, we have focused on $\mathrm{L} 1$, an integral membrane glycoprotein expressed exclusively on postmitotic neurons in the CNS and on neurons and Schwann cells in the PNS (Schachner et al., 1989). L1 mediates neuron-neuron adhesion in a calciumindependent manner and is involved in migration of granule cells in the early postnatal cerebellar cortex (Lindner et al., 1983; Rathjen and Schachner, 1984), fasciculation of neurites (Fischer et al., 1986), and neurite outgrowth and neuron-Schwann cell interaction during myelin formation (Seilheimer and Schachner, 1987). Mouse L1 is very similar in structure, function, and distribution (Bock et al., 1985; Stallcup and Beasley, 1985; Sajovic et al., 1987) to the NGF-inducible large external glycoprotein (NILE) (McGuire et al., 1978) and to chicken Ng-CAM (Grumet and Edelinan, 1984). Sequence analysis of cDNAs (Moos et al., 1988; Burgoon et al., 1991; Miura et al., 1991; Prince et al., 1991) indicates that these molecules are homologs.

McGuire et al. (1978) have reported that the NGF-induced increase in NILE is selectively inhibited by the RNA synthesis inhibitor camptothecin and, hence, appears to be mediated through a transcriptional pathway. By contrast, recent studies have suggested that mRNA levels for LI and NILE are not altered following exposure to NGF in PC12 cells (Sajovic et al., 1987; Miura et al., 1991; Prince et al., 1991). To understand these different results, we have carried out a thorough investigation of the conditions required for NGF induction of $\mathrm{L} 1$ mRNA in PC12 cells.

The experiments described here test three aspects of this regulation: (1) Does NGF regulate the level of L1 mRNA in PC12 cells? (2) Are the mechanism(s) by which NGF regulates morphological differentiation in PC12 cells identical to those by which it regulates L1? (3) Does cell-cell or cell-extracellular matrix adhesion regulate $\mathrm{L} 1$ expression? The results indicate that NGF affects cell morphology and L1 gene expression by distinct mechanisms. The results further suggest that cell-cell contact, involving homophilic L1-L1 contact, but not cell-extracellular matrix contact, modulates the effect of NGF on L1 mRNA levels.

\section{Materials and Methods}

Cell culture. Rat pheochromocytoma cells (PC12), originally developed by Greene and Tischler (1976), were the gift of Dr. K. Neet, Case 
Western Reserve University. These cells were maintained in a humidified $10 \% \mathrm{CO}_{2}$ atmosphere at $37^{\circ} \mathrm{C}$ in $85 \%$ Dulbecco's modified Eagle's medium containing $5 \%$ fetal calf serum, $10 \%$ donor horse serum, 100 $\mathrm{U} / \mathrm{ml}$ penicillin $\mathrm{G}, 100 \mu \mathrm{g} / \mathrm{ml}$ streptomycin, and $250 \mathrm{ng} / \mathrm{ml}$ amphotericin B. At confluency, the cells were dislodged from the culture flask (Falcon, \#3111, Bedford, MA) by shaking and trituration and $25 \%$ of these cells were transferred into new culture flasks weekly. The culture medium was changed every 2-3 d. For total cellular RNA isolation, cells were plated on rat tail collagen (COL, $50 \mu \mathrm{g} / \mathrm{ml})$, BSA $(50 \mu \mathrm{g} / \mathrm{ml})$, poly-L-lysine ( $\mathrm{PL}, 50 \mu \mathrm{g} / \mathrm{ml}$ ), laminin $(\mathrm{LN}, 50 \mu \mathrm{g} / \mathrm{ml})$, or fibronectin (FN, $50 \mu \mathrm{g} / \mathrm{ml}$ )-coated $60 \mathrm{~mm}$ tissue culture dishes (Falcon, \#3002, Bedford, MA) at $0.5-4 \times 10^{4}$ cells per $\mathrm{cm}^{2}$ in serum-free, chemically defined medium consisting of DMEM/Ham's F12 (1:1) (Sigma, St. Louis, MO) and $15 \mathrm{~mm}$ HEPES supplemented with progesterone $(62 \mathrm{ng} / \mathrm{ml})$, putrescine $(16.1 \mu \mathrm{g} / \mathrm{ml})$, sclenium (39 $\mathrm{ng} / \mathrm{ml})$, insulin $(10 \mu \mathrm{g} / \mathrm{ml})$, and transferrin $(100 \mu \mathrm{g} / \mathrm{ml})$. In some experiments, cells were cultured in suspension at $80 \mathrm{rpm}$ to prevent outgrowth of neurites and adhesion to the substrate. To obtain conditioned medium, fresh medium was added to near-confluent cultures of PC12 cells and then harvested $48 \mathrm{hr}$ later, centrifuged to remove debris, and stored at $-20^{\circ} \mathrm{C}$. To test the effects of conditioned medium, PC12 cells were grown in fresh medium for $24 \mathrm{hr}$, before replacement by medium consisting of $50 \%$ conditioned medium and $50 \%$ fresh medium. To determine the role of gp140 control PC12 cells and gp140 $10^{r k}$-negative PC12nnrs cells (kindly provided by Dr. S. H. Green, University of Iowa) were grown in serumcontaining RPMI1640 medium (Greene et al., 1987). Donor horse serum was purchased from JRH Bioscience (Lenexa, KS); all other media and reagents were obtained from GIBCO/BRL (Grand Island, NY).

Isolation and cloning of a mouse LI segment. A partial L1 CDNA was obtained by PCR using adult mouse brain CDNA as template. The upstream and downstream primers were 5'GACGAATTCAAAGGACACCATGTGC-3' and 3'-CCGGTTACTGTGACCTGCGATAAAG$5^{\prime}$, corresponding to nucleotides 70-95 and 1461-1486, respectively, of the mouse L1 cDN $\Lambda$ sequence of Moos et al. (1989). These primers were designed to enable cloning of IgG-like loops I to V of L1. The resulting PCR product was approximately $1.8 \mathrm{~kb}$, as expected. After digestion with EcoRI and SacI, a $1.28 \mathrm{~kb}$ fragment was obtained and cloned into pATH20 for production of fusion protein.

Production of antibody to L1. Bacterial expression and purification of the fusion protein derived from pATH20 were carried out according to the method of Koerner et al. (1991). The fusion protein was electrophoretically eluted from a polyacrylamide gel after electrophoresis, mixed with Freund's complete adjuvant (Difco, Detroit, MI) in $10 \mathrm{~mm}$ Tris- $\mathrm{HCl}, \mathrm{pH} 7.4$, and $15.5 \mathrm{mM} \mathrm{NaCl}$, and injected into New Zealand White rabbits (Charles River, Boston, MA) at a dose of $0.5 \mathrm{mg}$ protein/injection. After the initial injection, rabbits were boosted five times at 3 week intervals with fusion protein $(0.5 \mathrm{mg})$ mixed with Freund's incomplete adjuvant as above and bled to collect antiserum. Antiserum obtained from the rabbits injected with fusion protein was immunoaffinity purified first by positive selection on a fusion protein column and then negative selection on a TrpE protein columns. The IgG fraction was purified using Protein A Sepharose Fast Flow (Pharmacia, Piscataway, NJ). An IgG fraction from a preimmune bleed from the same rabbit was used as a control.

RNA isolation and Northern blot analysis. Total cellular RNA was isolated by the method of Chomcynski and Sacchi (1987). For Northern blot analysis, RNA ( $10 \mu \mathrm{g} / \mathrm{lane})$ was electrophoresed on $0.8 \%$ agarose gels containing $0.66 \mathrm{M}$ formaldehyde, and capillary transferred overnight to GeneScreen Plus membrane (DuPont NEN, Boston, MA). Membranes were baked at $80^{\circ} \mathrm{C}$ for $2 \mathrm{hr}$ under vacuum and then prehybridized for at least $30 \mathrm{~min}$ at $63^{\circ} \mathrm{C}$ in $1 \mathrm{M} \mathrm{NaCl}, 1 \%$ SDS and $10 \%$ dextran sulfate. DNA probes were labeled with $\left[\alpha^{-32} \mathrm{P}\right]-\mathrm{dCTP}(6000$ $\mathrm{Ci} / \mathrm{mmol}$, Dupont NEN, Boston, MA) by the random primer labeling method (Feinberg and Vogelstein, 1983) and purified on a Sephadex G-50 (Pharmacia, Piscataway, NJ) column. The labeling efficiency was more than $1.0 \times 10^{9} \mathrm{cpm} / \mu \mathrm{g}$ DNA. The $\mathrm{L} 1 \mathrm{cDNA}$ probe used was the $1280 \mathrm{bp}$ EcoRI/SacI fragment. A $780 \mathrm{bp}$ PstI/XbaI fragment of the cDNA coding for human glyceraldehyde 3-phosphate dehydrogenase (GPDH) (ATCC, Rockville, MD) was used as reference probe (Batistatou et al., 1992). Levels of GPDH mRNA were unchanged over the same period in the presence or absence of NGF. The two labeled probes were added together with denatured salmon testis DNA $(100 \mu \mathrm{g} / \mathrm{ml}$, Sigma, St. Louis, MO) to the prehybridization buffer. Hybridization of the radiolabeled probe $\left(1-2 \times 10^{6} \mathrm{dpm} / \mathrm{ml}\right)$ was performed for $20-24$ hr under the same conditions as above. The hybridized membranes were washed twice in $2 \times$ SSC for $5 \mathrm{~min}$ at rom temperature, twice in $2 \times$ SSC and $1 \%$ SDS for $30 \mathrm{~min}$ at $63^{\circ} \mathrm{C}$, and then twice in $0.1 \times \mathrm{SSC}$ and $1 \%$ SDS for $30 \mathrm{~min}$ at room temperature. Membranes were exposed to $\mathrm{X}$-ray film (Kodak X-OMAT AR) at $-70^{\circ} \mathrm{C}$ with an intensifying screcn. The L1- and GPDH-specific bands in the autoradiographs were semiquantified by scanning using an imaging densitometer (Model-620, BioRad, Melville, NY). The values obtained for L1 mRNA were normalized by dividing by the values obtained for GPDH mRNA.

Western blotting analysis. Plasma membranes were isolated from PC12 cells by the method of Itoh et al. (1992). Briefly, cultured PC12 cells were homogenized in $2.5 \mathrm{ml}$ of homogenization buffer: phosphatebuffered saline containing $0.2 \mathrm{mM} \mathrm{CaCl}, 0.2 \mathrm{mM} \mathrm{MgCl}_{2}, 1.0 \mathrm{mM}$ spermidine, $1.0 \mathrm{~mm} \mathrm{NaHCO}, 10 \mu \mathrm{g} / \mathrm{ml}$ soybean trypsin inhibitor, $10 \mu \mathrm{g} / \mathrm{ml}$ eggwhite trypsin inhibitor, $1.0 \mathrm{~mm}$ phenylmethyl sulfonyl fluoride, 0.5 $\mathrm{mm}$ iodoacetamide, $0.1 \mathrm{~mm}$ leupepsin and $40 \mathrm{U} / \mathrm{ml}$ aprotinin at $\mathrm{pH}$ 7.9. The homogenate was centrifuged for $20 \mathrm{~min}$ at $1200 \times g$ at $4^{\circ} \mathrm{C}$. The pellet was reextracted twice and the combined supernatants were centrifuged for $30 \mathrm{~min}$ at $30,000 \times g$ at $4^{\circ} \mathrm{C}$. This pellet was solubilized in $5 \mathrm{ml}$ of solubilization buffer ( $25 \mathrm{~mm}$ Tris, $150 \mathrm{mM} \mathrm{NaCl}, \mathrm{pH} 8.2$ ) containing $0.1 \%$ deoxycholate and protease inhibitors as described above and centrifuged for $1 \mathrm{hr}$ at $100,000 \times g$ at $4^{\circ} \mathrm{C}$. The final supernatant was used as a crude membrane fraction. Sodium dodecyl sulfatepolyacrylamide gel electrophoresis (SDS-PAGE) analysis was performed on 6\% polyacrylamide gels (Laemmli, 1970). In order to examine L1 polypeptide levels in PC12 cells, proteins fractionated by SDS-PAGE were transferred to Immobilon ${ }^{\left(\mathbb{N}_{-}\right.}-\mathrm{P}$ (Millipore, Bedford, MA) and processed for Western blot analysis with polyclonal L1 antibody and biotinylated anti-rabbit IgG antibody using Vectastain ${ }^{1} \mathrm{ABC}$ reagent and diaminobenzidine as the peroxidase substrate for horseradish peroxidase-staining according to the manufacturer's instructions (Vector, Burlingame, CA).

Growth factors and other reagents. Growth factors and other factors were added to cultures at the time of plating and were replenished every 2-3 d. 2.5S NGF and FGF were purchased from Collaborative Biomedical Products (Bedford, MA). TGF $\beta$ and EGF were obtained from Genzyme (Cambridge, MA) and GIBCO/BRL (Grand Island, NY), respectively. All growth factors were diluted in PBS containing $100 \mu \mathrm{g} / \mathrm{ml}$ BSA. Controls received vehicle only. A $2 \mathrm{~mm}$ stock solution of K252a (Calbiochem, La Jolla, CA) was prepared in dimethylsulfoxide and stored at $-20^{\circ} \mathrm{C}$ in the dark. $N, 2^{\prime}$-dibutyryladenosine $3^{\prime}, 5^{\prime}$-cyclic monophosphate (dbcAMP) was obtained from Sigma (St. Louis, MO) and dissolved in culture medium immediately before use.

Statistical analysis. All data were represented as means \pm SD from at least three independent experiments. Statistical analyses of all data were performed by ANOVA.

\section{Results}

\section{Nerve growth factor induces $L 1 \mathrm{mRNA}$}

To characterize the molecular mechanisms underlying the regulation of L1 expression, the kinetics of expression of L1 mRNA in PC12 cells following treatment with NGF were determined. PC12 cells were exposed to $50 \mathrm{ng} / \mathrm{ml} \mathrm{NGF}$, and total cellular RNA was isolated 0-7 d later. Northern blot analysis revealed that L1 mRNA specific activity increased fourfold during $7 \mathrm{~d}$ in culture (Figs. $1 A, B$ ). This change was gradual and peaked at 5 $\mathrm{d}$ of treatment. In untreated control cultures, no significant changes in L1 mRNA were observed. In these experiments, a single $6.0 \mathrm{~kb} \mathrm{L1}$ mRNA was detected, as reported previously (Tacke et al., 1987; Miura, et al., 1991). Roughly equal amounts of RNA were found to have been loaded when each of the lanes was probed for GPDH (Fig. $1 B$; lower bands) and there was no obvious effect of NGF treatment on the GPDH/total RNA ratio. To compare the time course of L1 mRNA induction by NGF with the well-known morphological differentiation of these cells caused by NGF, the cultures were photographed before RNA harvest. NGF-induced neurites were readily visible after $1 \mathrm{~d}$ of treatment and were prominent after $5 \mathrm{~d}$ (Fig. 1C). Thus, the time course of NGH induced morphological differentiation paralleled that of L1 mRNA induction. Similar results were obtained when $\mathrm{PC} 12$ cells were cultured in serum-containing medium (data not 
A

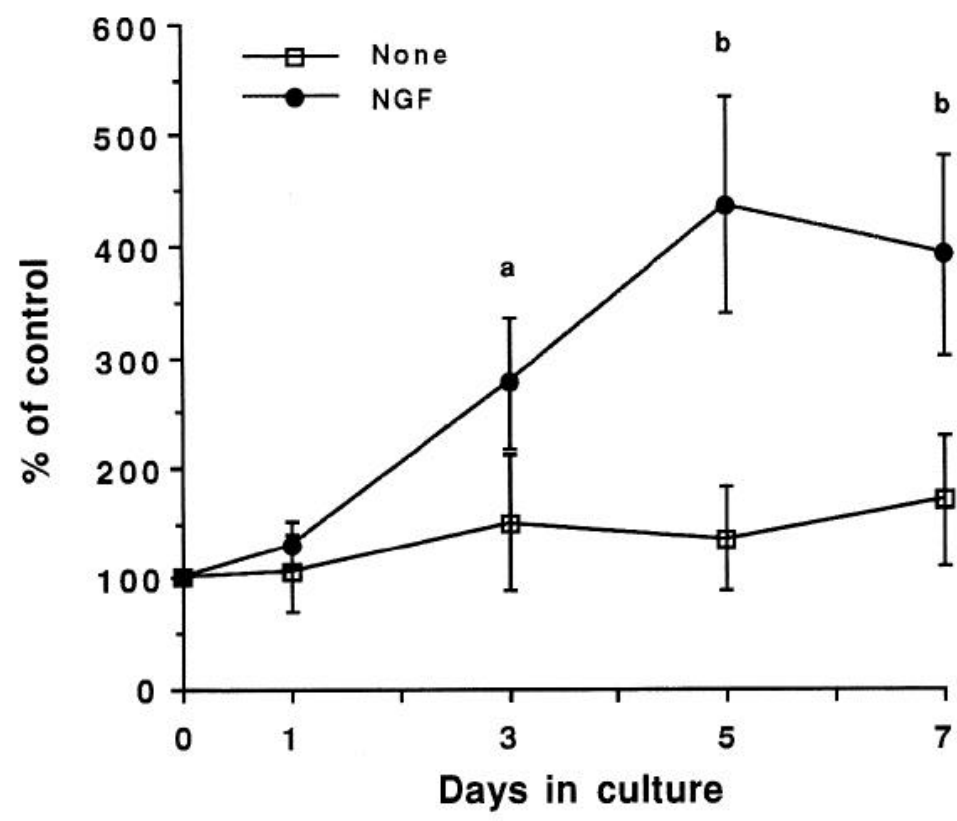

B
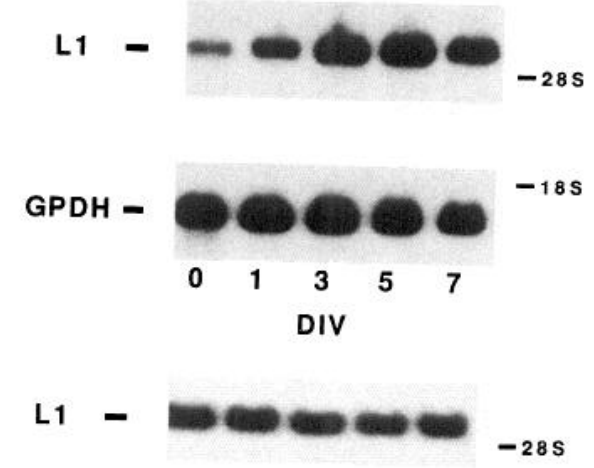

GPDH -

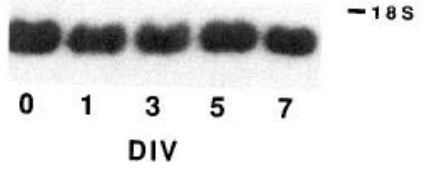

C

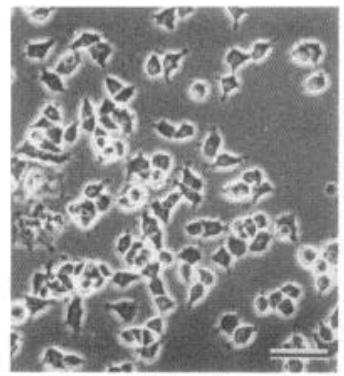

0

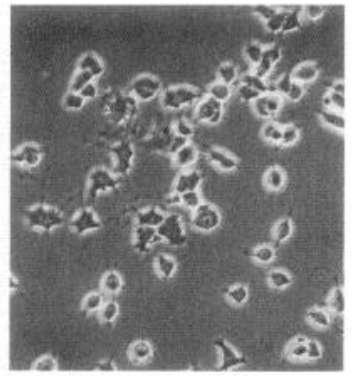

1

Days

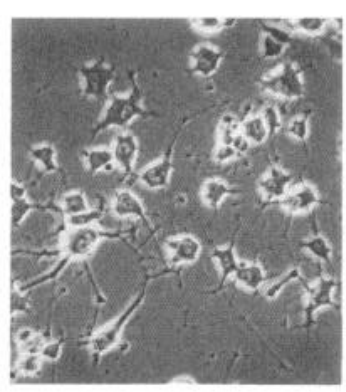

5
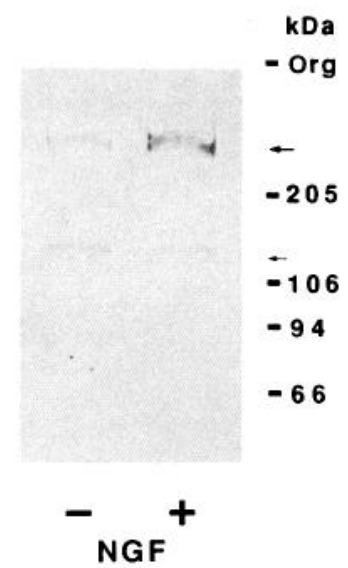

Figure 1. Time course of NGF-induced changes in L1 mRNA levels. A, PC12 cells were cultured for various time intervals in hormonesupplemented chemical-defined medium with $(\mathbf{)}$ or without $(O) 50 \mathrm{ng} / \mathrm{ml} \mathrm{NGF}$ and L1 mRNA levels were determined as described in Materials and Methods. L1 mRNA levels (means \pm SD from four independent experiments) are expressed as the percentage of the relative intensity obtained at $0 \mathrm{~d}$. Statistical differences were analyzed as compared with growth without NGF; $a, p<0.05 ; b, p<0.01$. B, Autoradiographs of typical Northern blots are presented in the upper panel $(+N G F)$ and the lower panel $(-N G F)$. $C$, Phase contrast micrographs illustrating typical PC12 cell morphologies at day 0, 1, and 5 following exposure to NGF $(50 \mathrm{ng} / \mathrm{ml})$. Scale bar, $25 \mu \mathrm{m}$. D, Western blot analysis of L1 in PC12 cells. Lane 1, PC12 cells grown for $5 \mathrm{~d}$; lane 2, NGF treated PC12 cells. L1 (upper band) is indicated by a large arrow; a small arrow shows nonspecific signal (lower band). Apparent molecular weights (in $\mathrm{kDa}$ ), determined from markers run in parallel, are indicated to the right.

shown). To confirm that L1 polypeptide levels also increased after treatment with NGF, Western blot analysis was performed. The L1 polypeptide level had clearly increased $5 \mathrm{~d}$ after treatment with NGF (Fig. 1D). These results suggest that the NGFinduced increase in L1 occurs via increased transcription or stability of L1 mRNA.

To further examine whether the morphological changes induced by NGF correlate with L1 mRNA expression, varying concentrations of NGF were used to treat cell cultures. PC12 cells treated with $3 \mathrm{ng} / \mathrm{ml} \mathrm{NGF}$ had neurites at least twice greater in length than that of the cell body at day 5 (Fig. 2). The length and density of neurites of PC12 cells appeared to be greater following treatment with a high dose $(100 \mathrm{ng} / \mathrm{ml})$ of NGF than with lower doses of NGF (Fig. $2 B$ ), while the L1 mRNA level induced by $100 \mathrm{ng} / \mathrm{ml}$ of NGF was not significantly higher than levels seen at $3 \mathrm{ng} / \mathrm{ml}$. In summary, these experiments demonstrated that NGF induced L1 mRNA expression in PC12 cells with a time course coincident with morphological differentiation, although the dose dependencies of morphological differentiation and of L1 mRNA induction appeared to differ slightly.

\section{MRNA is specifically induced by NGF}

To determine whether the induction of L1 was specific to NGF, other growth factors and agents were examined for their ability to induce L1 mRNA levels. This question is of particular interest because agents such as FGF and dbcAMP have been shown to 

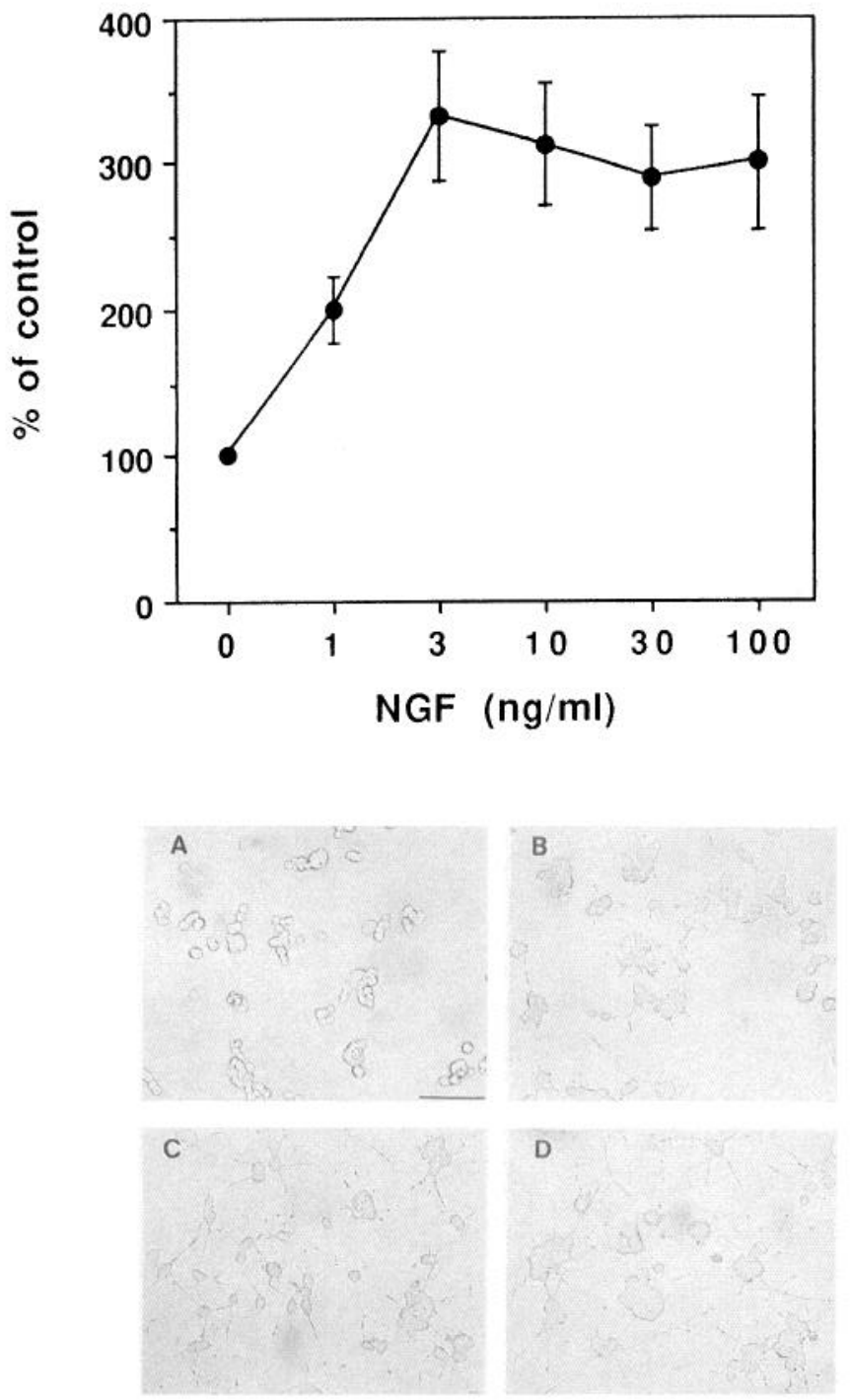

D

Figure 2. The effect of various doses of NGF on expression of L1 mRNA. L1 mRNA levels were determined as described in Materials and Methods. The upper panel shows L1 mRNA levels in PC12 cells cultured for $5 \mathrm{~d}$ in the presence of $1-100 \mathrm{ng} / \mathrm{ml}$ NGF. L1 mRNA levels (means \pm SD from five independent experiments) are expressed as a percentage of the $0 \mathrm{ng} / \mathrm{ml} \mathrm{NGF-treated} \mathrm{culture.} \mathrm{The} \mathrm{bottom} \mathrm{panel} \mathrm{shows}$ phase contrast micrographs of PC12 cell morphology after $5 \mathrm{~d}$ treatment with NGF $(A, 0 \mathrm{ng} / \mathrm{ml} ; B, 1 \mathrm{ng} / \mathrm{ml} ; C, 3 \mathrm{ng} / \mathrm{ml} ; D, 100 \mathrm{ng} / \mathrm{ml})$. Scale bar, $50 \mu \mathrm{m}$.

induce morphological differentiation of PC12 cells (Gunning et al., 1981; Rydel and Greene, 1987). Treatment for $5 \mathrm{~d}$ with FGF, EGF, TGF $\beta$, or dbcAMP did not cause any significant change in L1 mRNA expression in PC12 cells (Fig. 3), although FGF and dbcAMP promoted neurite outgrowth as effectively as NGF (data not shown). These results indicated that, although the neurite extension induced by FGF and dbcAMP was morphologically indistinguishable from that induced by NGF, L1 mRNA was induced only by NGF treatment. Thus, L1 mRNA is specifically induced by NGF treatment and is not an obligatory consequence of morphological differentiation of the cells.

$N G F$ regulation of $L 1 \mathrm{mRNA}$ is not associated with gp $140^{\mathrm{rak}}$

NGF selectively binds to and activates gp140 ${ }^{r k}$, a transmembrane protein tyrosine kinase (Chao, 1992). To examine whether
NGF effects on L1 expression are mediated via gp140 14 , we tested the effect of $\mathrm{K} 252 \mathrm{a}$, an inhibitor of the tyrosine kinase activity of gp140 ${ }^{r k k}$ (Berg et al., 1992). K252a (200 nM) did not inhibit NGF induction of L1 mRNA (Table 1), although this concentration completely inhibited the extension of neurites by these PC12 cells (Fig. 4). This result suggests that gp140 ${ }^{\text {rrk }}$ may not mediate the effects of NGF on expression of L1 mRNA. To further test this idea, we determined the effect of NGF on L1 mRNA levels in PC12nnr5 cells, which specifically lack gp140 ${ }^{\text {rk }}$. As shown in Figure 5, Northern blot analysis of RNA isolated from $\mathrm{PC} 12$ and $\mathrm{PC} 12 \mathrm{nnr} 5$ cells after treatment with 0 ,

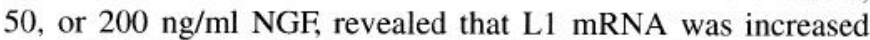
1.9-fold in PC12nnr5 cells treated with $200 \mathrm{ng} / \mathrm{ml}$, although this treatment did not induce neurite outgrowth in PC12nnr5 cells. Together, these findings indicate that induction of L1 mRNA in PC12 cells by NGF does not require the high-affinity NGF receptor.

\section{Levels of $L 1 \mathrm{mRNA}$ are increased by cell-cell contact}

To determine whether L1 mRNA expression is influenced by cell-cell contact, $\mathrm{PC} 12$ cells were plated at cell densities ranging from 0.5 to $4 \times 10^{4} \mathrm{cells} / \mathrm{cm}^{2}$ and cultured for $5 \mathrm{~d}$ in the absence of NGF. Within this range of cell densities, L1 mRNA levels did not increase in proportion to the increases in cell density in the absence of NGF (Fig. 6). In the presence of NGF, however, PC12 cells grown at high cell density $\left(4 \times 10^{4}\right.$ cells $\left./ \mathrm{cm}^{2}\right)$ expressed twofold higher levels of L1 mRNA than cells grown at low cell density $\left(5 \times 10^{3}\right.$ cells $\left./ \mathrm{cm}^{2}\right)$ (Fig. 6). Moreover, L1 mRNA levels in NGF-treated PC12 cells at high cell density were approximately eightfold greater than in untreated cells (Fig. 6). To test whether this effect resulted from cell-cell contact or accumulation of soluble factors, PC12 cells at low cell density were cultured in the presence or absence of medium that had been conditioned by cells growing at high cell density. As shown in Figure 7 , the conditioned medium did not enhance the effect of NGF on L1 mRNA in cells at low density. To examine further whether cell-cell contact modulates NGF-induction of L1 mRNA, we tested whether homophilic L1 to L1 binding could play a role in cell-cell contact-mediated regulation of L1 mRNA expression. $\mathrm{PC} 12$ cells maintained at low cell density $\left(5 \times 10^{3}\right.$ cells $/ \mathrm{cm}^{2}$ ) with or without NGF were treated with antibody to L1 to mimic homophilic L1-L1 interaction (Schuch et al., 1989; Atashi et al., 1992; Itoh et al., 1992; von Bohlen und Halbach et al., 1992). Treatment with antibody to L1 alone did not increase L1 mRNA above the basal level, but the combination of NGF and antibody to L1 significantly increased (40\%) L1 mRNA levels above the level induced by NGF alone (data not shown). In contrast, treatment with antibodies to N-CAM had no effect on NGF induction of L1 mRNA. These observations suggest that homophilic L1-L1 binding may be one of the mechanisms by which cell-cell contact influences the ability of NGF to increase L1 mRNA levels.

\section{Cell-extracellular matrix contact does not regulate expression of $L I m R N A$}

To assess whether cell-extracellular matrix contact could also influence L1 mRNA levels, PC12 cells were plated on different substrates (BSA, PL, COL, LN, and FN) in the presence or absence of NGF and L1 mRNA expression was assessed. In the absence of NGF, no increase in L1 mRNA was observed when PC12 cells were cultured for $5 \mathrm{~d}$ on any of the extracellular matrix components. When cultured with NGF, the increase in 


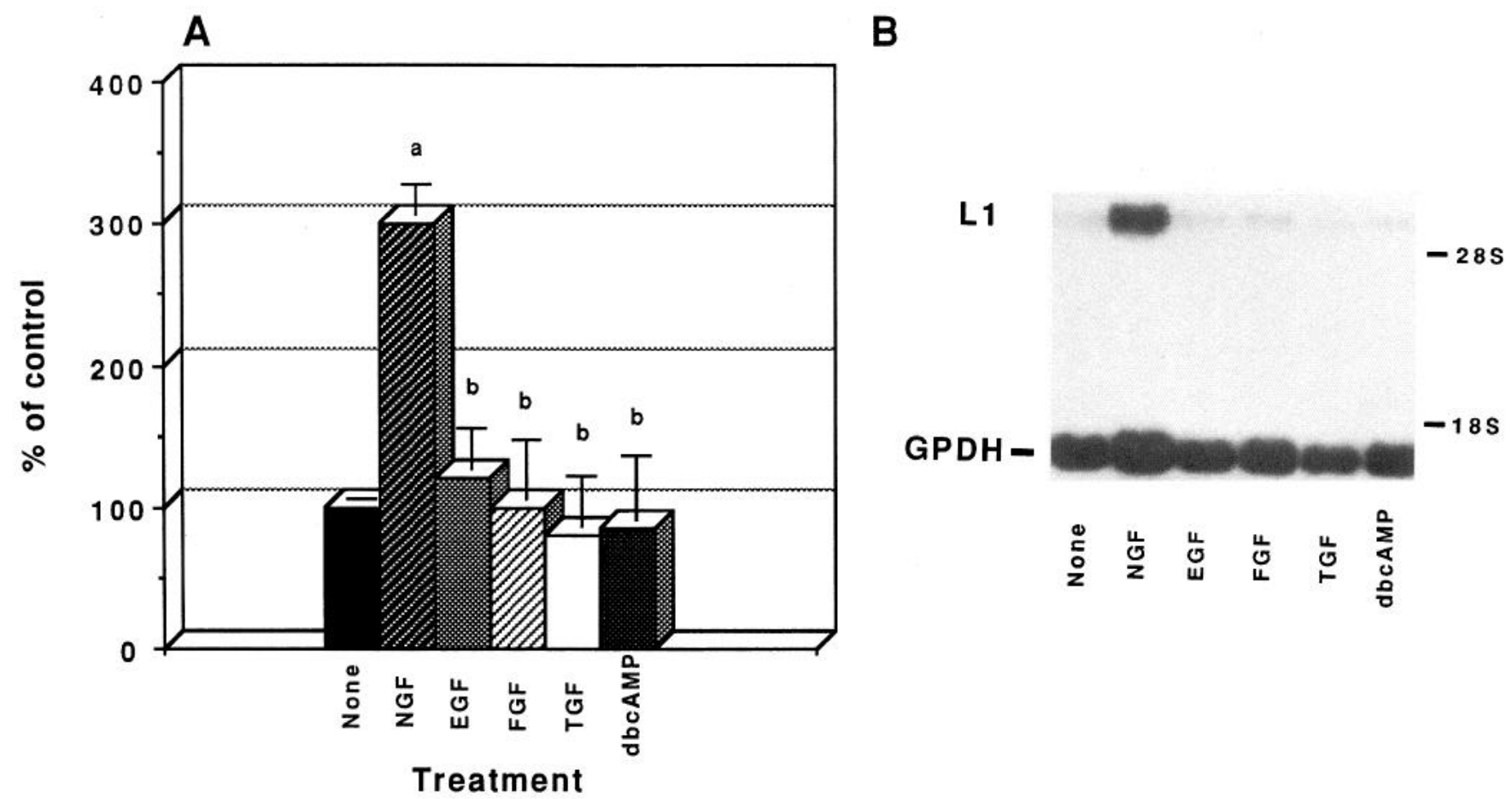

Figure 3. Effects of various growth factors and agents on L1 mRNA expression in PC12 cells. A, PC12 cells were cultured for 5 d with NGF $(50 \mathrm{ng} / \mathrm{ml})$, EGF $(10 \mathrm{ng} / \mathrm{ml})$, FGF $(100 \mathrm{ng} / \mathrm{ml})$, TGF $(50 \mathrm{ng} / \mathrm{ml})$ and dbcAMP $(1 \mathrm{~mm})$. Ll mRNA levels (means \pm SD from at least three independent experiments) were represented as the percentage of untreated cultures. Statistical differences were analyzed as compared with growth without NGF; $a, p<0.01 ; b$, not significant. $B$, Autoradiographs of typical Northern blots showing L1 mRNA (upper band) and GPDH mRNA (lower band).

L1 mRNA (approximately threefold) was similar on all substrates (Fig. 8). Furthermore, L1 mRNA levels also increased approximately three- to fourfold following exposure to NGF when PC12 cells were grown in suspension, to prevent cellsubstrate adhesion and neurite extension (data not shown). In conclusion, these results imply that, for the substrates tested, cell-substrate adhesion does not significantly influence the expression of L1 mRNA.

\section{Discussion}

In the present study, we have established that L1 mRNA levels in PC12 cells are specifically enhanced by NGF, leading to increased expression of $\mathrm{L} 1$ at the cell surface. Strikingly, our findings suggest that the effect of NGF on L1 expression is not mediated by the high-affinity NGF receptor, gp140 14 . These NGF-induced changes in L1 expression were facilitated by cell to cell interactions, but were not affected by the interactions of $\mathrm{PC} 12$ cells with several extracellular matrix components.

Table 1. Effect of K252a on L1 mRNA levels in PC12 cells

\begin{tabular}{lll} 
Treatment & Concentration & $\begin{array}{l}\text { L1 mRNA } \\
\text { (\% of control) }\end{array}$ \\
\hline None & & $100 \pm 12$ \\
NGF & $4 \mathrm{~nm}$ & $343 \pm 36^{a}$ \\
NGF + K252a & $4 \mathrm{~nm}+200 \mathrm{~nm}$ & $345 \pm 55^{b}$
\end{tabular}

The levels of L1 mRNA were determined by Northern blot analysis (see Materials and Methods). The values represent the means \pm SD of three or more determinations.

${ }^{a} p<0.01$, None versus NGF.

'Not significant, NGF versus NGF + K252a.
NGF influences both the levels of protein and mRNA for several neuron-related proteins in PC12 cells including NCAM, Thy-1, and neurofilaments (Doherty et al., 1987; Prentice et al., 1987; Lindenbaum et al., 1988). In contrast, recent studies suggest that mRNA levels for L1 do not change following exposure to NGF in PC12 cells, although L1 polypeptide levels increase (Sajovic et al., 1987; Prince et al., 1989; Miura et al., 1991). We have reexamined this potential discrepancy by determining the kinetics of expression of L1 mRNA and polypeptide in the continual presence of NGF using Northern and Western blot analyses, respectively. The level of L1 mRNA increased slowly over the $5 \mathrm{~d}$ period of NGF treatment and by then the amount of L1 protein was sufficiently higher than in nontreated cells to be readily detectable in Western blotting. After $5 \mathrm{~d}$ treatment with NGF, the level of L1 mRNA declined slightly; previous studies determined this level at $7 \mathrm{~d}$, so that the difference between NGFtreated and untreated cultures was not as large as the maximal difference we saw. This lesser difference may have been difficult to detect without accurate internal controls for RNA loading, such as were performed in our study. The timing of the increase in L1 mRNA suggests that L1, like NCAM (Prentice et al., 1987), is a member of the class of late genes that are induced only after several hours to days of NGF treatment.

Several of the studies reported here bear on the mechanism by which NGF affects L1 expression. The high-affinity NGF receptor has recently been identified as gp140 ${ }^{\text {rk }}$ (Kaplan et al., 1991a,b). NGF binds directly to homodimer gp $140^{t r k}$, activating its tyrosine kinase activity (Jiug et al., 1992). gp140 trk is phosphorylated in a dose-dependent manner in the range of $0.1-100$ $\mathrm{ng} / \mathrm{ml}$ NGF. Increasing the concentration of NGF effectively induces not only the phosphorylation of gp140 $0^{\text {rrk }}$, but also neuronal 

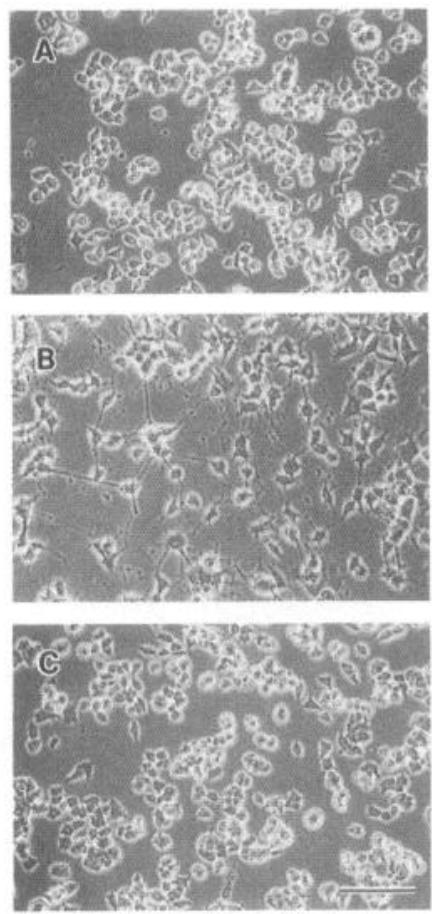

Figure 4. Effect of K252a on morphology of NGF-treated PC12 cells. PC12 cells were cultured for $5 \mathrm{~d}$ in the absence $(A)$ and the presence of NGF $(50 \mathrm{ng} / \mathrm{ml})(B)$ or in the presence of NGF plus K252a (200 nM) (C). Scale bar, $50 \mu \mathrm{m}$. differentiation of PC12 cells (Loeb et al., 1991; Hempstead et al., 1992).

Several of the results support the idea that NGF might affect morphological differentiation and L1 mRNA levels via distinct mechanisms. The observation that NGF increased L1 mRNA expression in suspension-cultured PC12 cells, which do not extend neurites, suggests that NGF does not affect L1 gene expression by the same mechanism that mediates its effects on morphological differentiation of $\mathrm{PC} 12$ cells, namely binding to gp $140^{r k}$. This suggestion was strongly supported by the finding that K252a, a specific inhibitor of gp140 $0^{r k}$ tyrosine kinase activity, which completely blocks NGF-induced neuronal differentiation (Koizumi et al., 1988; Berg et al., 1992), has no effect on NGF induction of L1 mRNA. Most important, L1 mRNA was induced by NGF in PC12nnr5 cells, which lack gp140 rrk, although the dose of NGF required was higher in PC12nnr5 cells. Higher doses may have been required because the level of lowaffinity NGF receptor in these cells is only $20-25 \%$ that of the parental PC12 line (Green et al., 1986). An even more intriguing possibility relates to recent observations that the high- and lowaffinity NGF receptors interact (Hempstead et al., 1991; Verdi et al., 1994). These observations raise the possibility that binding of NGF to a heterodimer of high- and low-affinity receptors triggers dual responses, one involving the gp $140^{\text {rrk }}$ tyrosine $\mathrm{ki}-$ nase and one proceeding from the $\mathrm{p} 75^{\text {LNGFR }}$ low-affinity receptor. In this view, the absence of these interactions in PC12nnr5 cells would contribute to the requirement for a higher dose of NGF. These findings are also consistent with the observation that L1

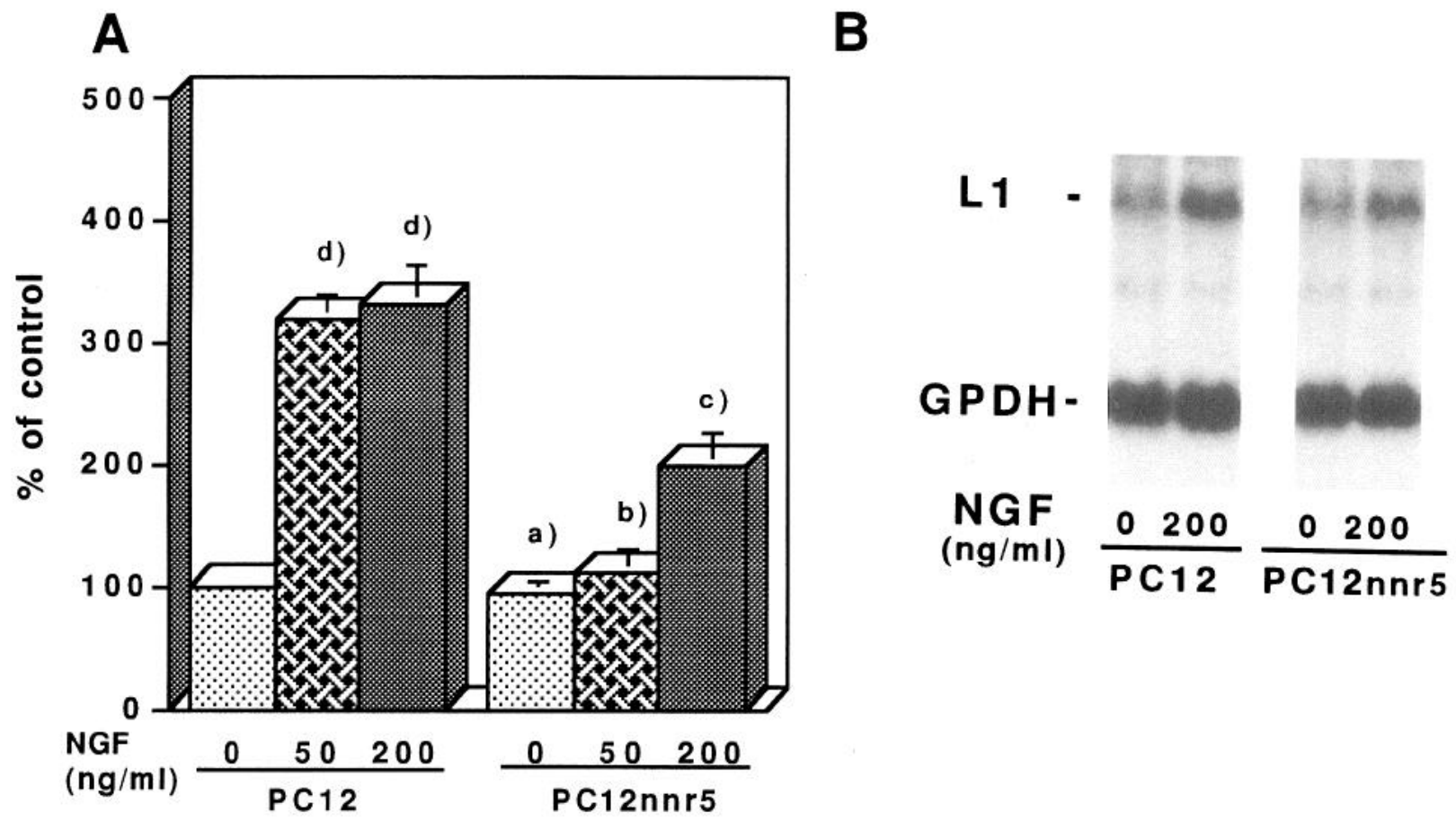

Figure 5. Effect of NGF on L1 mRNA in PC12nnr5 cells. A, PC12 and PC12nnr5 cells were cultured for $5 \mathrm{~d}$ in the presence of NGF ( 0 , 50 , and $200 \mathrm{ng} / \mathrm{ml}$ ). The results (means \pm SD from three to five independent experiments) were expressed as the percentage of untreated cultures. Statistical differences were analyzed as compared with growth without NGF in PC12 cells: $a$, not significant; $d, p<0.05$; and in PC12nnr5 cells: $b$, not significant; $c, p<0.01$. B. Autoradiographs of typical Northern blots showing L1 mRNA (upper band) and GPDH mRNA (lower band). 


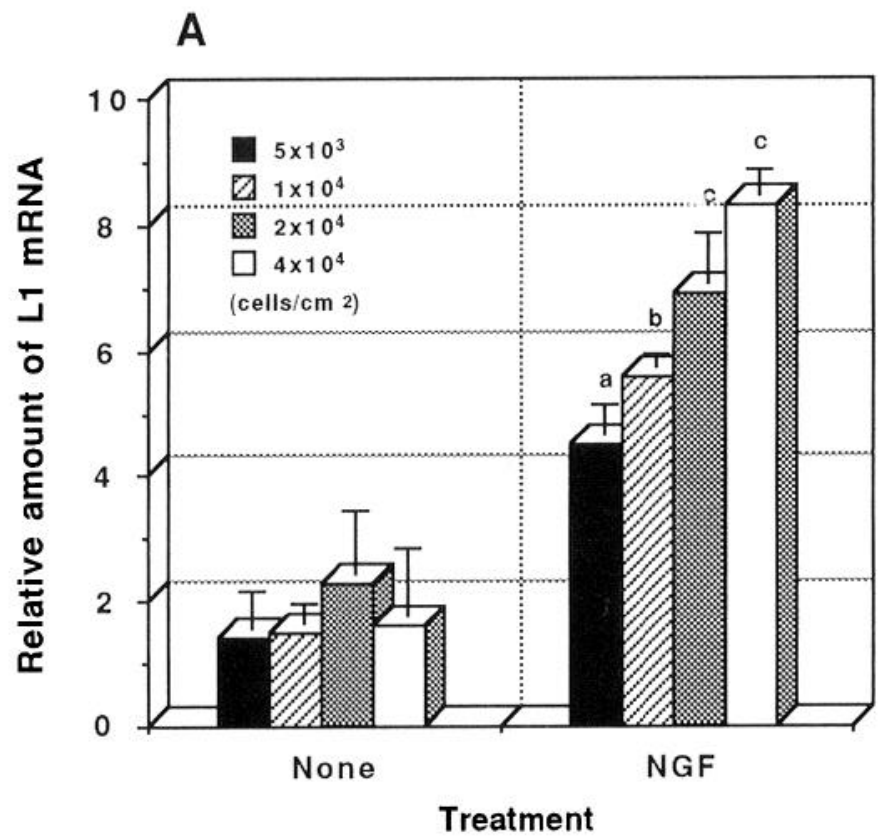

B

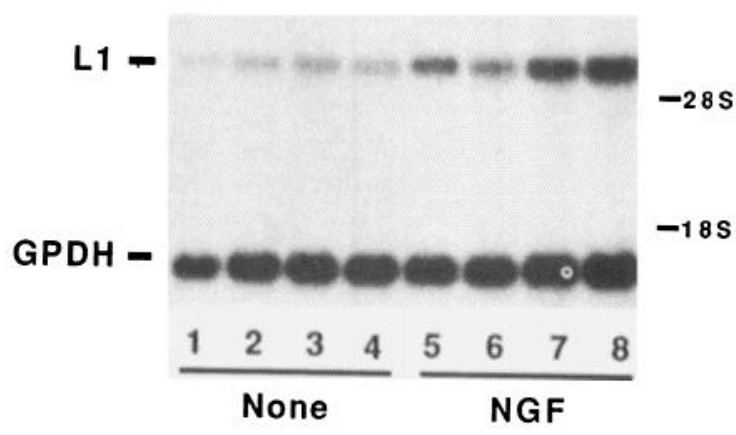

Figure 6. Effects of cell density on L1 mRNA levels in PC12 cells. $A, \mathrm{PC} 12$ cells were cultured for $5 \mathrm{~d}$ at various densities $\left(0.5-4 \times 10^{4}\right.$ cells $\left./ \mathrm{cm}^{2}\right)$ in the presence (left) or absence (right) of NGF $(50 \mathrm{ng} / \mathrm{ml})$. The results (means \pm SD from four independent experiments) were expressed as the fold increase relative to the values measured in cells cultured at $0.5 \times 10^{3}$ cells $/ \mathrm{cm}^{2}$ in the absence of NGF. Statistical differences were analyzed as compared with growth at $0.5 \times 10^{3}$ cells $/ \mathrm{cm}^{2}$ in the absence of NGF ( $a$, no significance), and with growth at $0.5 \times$ $10^{3}$ cells $/ \mathrm{cm}^{2}$ in the presence of NGF $(b, p<0.05 ; c, p<0.01) . B$, Autoradiographs of typical Northern blots showing L1 mRNA (upper band) and GPDH mRNA (lower band). RNA was extracted from cells cultured in the absence (lanes 1-4) or presence (lanes 5-8) of NGF at densities of $0.5 \times 10^{3}$ cells $/ \mathrm{cm}^{2}$ (lanes 1 and 5 ), $1 \times 10^{4}$ cells $/ \mathrm{cm}^{2}$ (lanes 2 and 6 ), $2 \times 10^{4}$ cells $/ \mathrm{cm}^{2}$ (lanes 3 and 7), and $4 \times 10^{4}$ cells $/ \mathrm{cm}^{2}$ (lanes 4 and 8 ).

expression in Schwann cells is increased by NGF even though these cells express only the low-affinity NGF receptor, p75 L.NGFR (Heumann et al., 1987; Seilheimer and Schachner, 1987; Johnson et al., 1988).

Taken together, these results strongly indicate that NGF induces Ll mRNA by a novel mechanism. By implication, it appears that the effect of NGF on L1 expression is mediated by the low-affinity NGF receptor (p75 L ${ }^{\text {LNGF }}$ ), although we have no evidence that this is the case. The observation that NGF binding to p75 LNGFR does not induce neurite outgrowth (Green et al., 1986; Loeb et al., 1991) is consistent with this suggestion, but

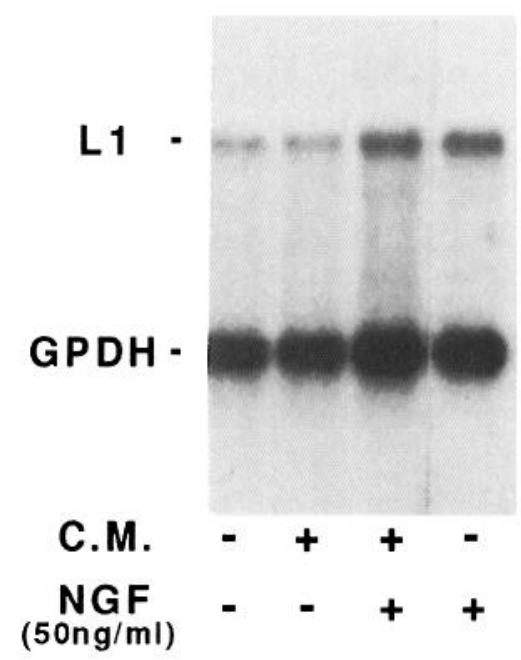

Figure 7. Effect of PC12 cell-conditioned medium on NGF stimulation of $\mathrm{L} 1 \mathrm{mRNA}$ levels in PC12 cells. The figure shows autoradiographs of typical Northern blots with L1 mRNA (upper band) and GPDH mRNA (lower band). Lanes contained RNA from cells cultured without additions (lane I), with conditioned medium alone (lane 2), 50 $\mathrm{ng} / \mathrm{ml}$ NGF plus conditioned medium (lane 3 ), or $50 \mathrm{ng} / \mathrm{ml} \mathrm{NGF}$ alone (lane 4).

further studies will be necessary to obtain a more complete understanding of the mechanisms involved.

The present study also indicated that the NGF-induced increase in L1 mRNA in PC12 cells is modulated by cell-cell interactions. The primary evidence supporting this conclusion was the observation that NGF induction of L1 mRNA was cell density-dependent when $\mathrm{PC} 12$ cells were cultured at different densities in the presence of NGF (Fig. 6). The cell density-dependence could be due to cell-cell contacts or to accumulation of autocrine factors. For example, an autocrine factor and serum factor appear to be responsible for the cell-density-dependent

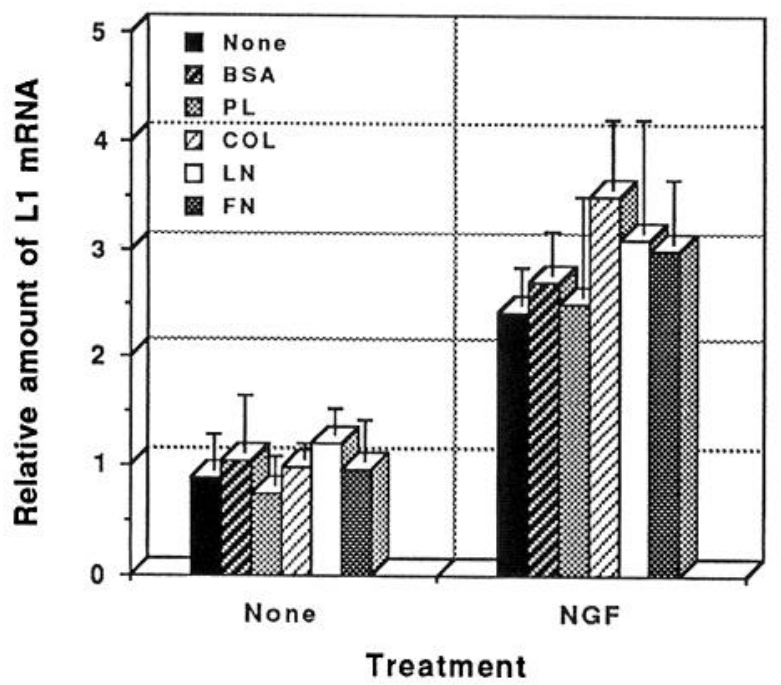

Figure 8. Effects of various extracellular matrix components on NGF induction of $\mathrm{Ll}$ mRNA. $A, \mathrm{PC} 12$ cells were cultured on collagen ( $C O L$, $50 \mu \mathrm{g} / \mathrm{ml}), B S A(50 \mu \mathrm{g} / \mathrm{ml})$, poly-L-lysine $(P L, 50 \mu \mathrm{g} / \mathrm{ml})$, laminin $(L N$, $50 \mu \mathrm{g} / \mathrm{ml})$, or fibronectin $(F N, 50 \mu \mathrm{g} / \mathrm{ml})$ for $5 \mathrm{~d}$ in the presence (right) or absence (left) of NGF $(50 \mathrm{ng} / \mathrm{ml})$. L1 mRNA levels (means \pm SD from four independent experiments) were expressed as the ratio of intensity values of $\mathrm{Ll}$ and GPDH. 
expression of NCAM in N2a cells (Roubin et al., 1990). In the present experiments, however, conditioned serum-containing medium did not enhance NGF stimulation of L1 mRNA levels, suggesting that density-dependent effects on NGF induction of L1 mRNA are not mediated by autocrine factors and serum, but by cell-cell contact. Additional supporting evidence came from the observation that antibodies to L1 (presumed to mimic L1L1 homophilic binding) enhanced the effect of NGF on PC12 cells cultured at low cell density. Previous studies have shown that homophilic interactions between L1 molecules trigger changes in intracellular calcium and phosphoinositides (Schuch et al., 1989; von Bohlen und Halbach et al., 1992; Itoh et al., 1992), which could lead to alterations in L1 gene expression. Finally, in contrast to the effect of cell-cell contact on L1 mRNA expression, our measurements of Ll mRNA levels in PC12 cells cultured on substrata coated with different extracellular matrix components suggested that the effect of NGF on the increase in Ll mRNA expression is not dramatically influenced by cell-substrate interactions.

These findings have some implications for the roles of NGF and Ll during neuronal recovery after injury in the PNS. L1 is known to increase at cell contact sites between growth cones and fasciculating axons upon transecting or crushing the sciatic nerve (Martini and Schachner, 1988). In addition, L1 expression in the PNS is regulated by NGF (Seilheimer and Schachner, 1987). The present results suggest that NGF produced by nerve injuries could stimulate L1 expression via the low-affinity NGF receptor at nerve injury sites. This expression could be further enhanced by L1 interactions between cells of the PNS. These mechanisms may serve to promote the axonal reextension during regeneration.

In summary, the present studies show that NGF stimulates L1 mRNA accumulation in PC12 cells and that this induction is modulated by cell-cell contact, including L1 homophilic binding, but not by cell-substrate interaction. A particularly interesting issue raised in this study is the suggestion, from several lines of evidence, that the effect of NGF on L1 expression is not mediated by the high-affinity NGF receptor. By implication, the low-affinity NGF receptor, which has no known physiological function, may be involved. Testing this possibility may open new avenues for investigating the functions of NGF in neuronal differentiation and regeneration.

\section{References}

Atashi JR, Klinz SG, Ingraham CA, Matten WT, Schachner M, Maness PF (1992) Neural cell adhesion molecules modulate tyrosine phosphorylation of tubulin in nerve growth cone membranes. Neuron $8: 831-842$.

Batistatou A, Volonte C, Greene LA (1992) Nerve growth factor employs multiple pathways to induce primary response genes in PC12 cells. Mol Biol Cell 3:363-371.

Berg MM, Sternberg DW, Parada LF, Chao MV (1992) K-252a inhibits nerve growth factor-induced trk proto-oncogene tyrosine phosphorylation and kinase activity. J Biol Chem 267:13-16.

Bock E, Richter LC, Faissner A, Schachner M (1985) Demonstration of immunochemical identity between the nerve growth factor-inducible large external (NILE) glycoprotein and the cell adhesion molecule L1. EMBO J 4:2765-2768.

Burgoon MP, Grumet M, Mauro V, Edelman GM, Cunningham BA (1991) Structure of the chicken neuron-glia cell adhesion molecule, Ng-CAM: origin of the polypeptides and relation to the Ig superfamily. J Cell Biol 112:1017-1029.

Chao MV, Bothwell MA, Ross AH, Koprowski H, Lanahan AA, Buck CR, Sehgal A (1986) Gene transfer and molecular cloning of the human NGF receptor. Science 232:518-521.

Chomczynski P, Sacchi N (1987) Single-step method of RNA isolation by acid guanidinium thiocyanate-phenol-chloroform extraction. Anal Biochem 162:156-159.

Doherty P, Mann DA, Walsh FS (1987) Cholera toxin and dibutyryl cyclic AMP inhibit the expression of neurofilament protein induced by nerve growth factor in cultures of naive and primed PC12 cells. J Neurochem 49:1676-1687.

Doherty P, Mann DA, Walsh FS (1988) Comparison of the effects of NGF, activators of protein kinase $C$, and a calcium ionophore on the expression of Thy-1 and N-CAM in PC12 cell cultures. J Cell Biol 107:333-340.

Feinberg AP, Vogelstein B (1983) A technique for radiolabeling DNA restriction endonuclease fragments to high specific activity. Anal Biochem 132:6-13.

Fischer G, Kunemund V, Schachner M (1986) Neurite outgrowth patterns in cerebellar microexplant cultures are affected by antibodies to the cell surface glycoprotein L1. J Neurosci 6:605-612.

Greene LA, Tischler AS (1976) Establishment of a noradrenergic clonal line of rat adrenal pheochromocytoma cells which respond to nerve growth factor. Proc Natl Acad Sci USA 73:2424-2428.

Greene LA, Burstein DE, Black MM (1982) The role of transcriptiondependent priming in nerve growth factor promoted neurite outgrowth. Dev Biol 91:305-316.

Greene LA, Aletta JM, Rukenstein A, Green ST (1987) PC12 Pheochromocytoma cells: culture, nerve growth factor treatment, and experimental exploitation. Methods Enzymol 147:207-216.

Green SH, Rydel RE, Connolly JL, Greene LA (1986) PC12 cell mutants that possess low- but not high-affinity ncrve growth factor receptors neither respond to nor internalize nerve growth factor. J Cell Biol 102:830-843.

Grumet M, Edelman GM (1984) Heterotypic binding between neuronal membrane vesicles and glial cells is mediated by a specific cell adhesion molecule. J Cell Biol 98:1746-1756.

Gunning PW, Landreth GE, Bothwell MA, Shooter EM (1981) Differential and synergistic actions of nerve growth factor and cyclic AMP in PC12 cells. J Cell Biol 89:240-245.

Hempstead BL, Martin L, Zanka D, Kaplan DR, Parada LF, Chao MV (1991) High-affinity NGF binding requires coexpression of the trk proto-oncogene and the low-affinity NGF receptor. Nature 350:678683.

Hempstead BL, Rabin SJ, Kaplan L, Reid S, Parada LF, Kaplan DR (1992) Overexpression of the $t r k$ tyrosine kinase rapidly accelerales nerve growth factor-induced differentiation. Neuron 9:883-896.

Heumann R, Lindholm D, Bandtlow C, Meyer M, Radeke MJ, Misko TP, Shooter E, Thoenen H (1987) Differential regulation of mRNA encoding nerve growth factor and its receptor in rat sciatic nerve during development, degeneration, and regeneration: role of macrophages. Proc Natl Acad Sci USA 84:8735-8739.

Itoh K, Kawamura H, Asou H (1992) A novel monoclonal antibody against carbohydrates of $\mathrm{L} 1$ cell adhesion molecule causes an influx of calcium in cultured cortical neurons. Brain Res 580:233-240.

Jing S, Tapley P, Barbacid M (1992) Nerve growth factor mediates signal transduction through trk homodimer receptors. Neuron 9:1067-1079.

Johnson EJ, Taniuchi M, DiStefano PS (1988) Expression and possible function of nerve growth factor receptors on Schwann cells. Trends Neurosci 11:299-304.

Kaplan DR, Hempstead BL, Martin ZD, Chao MV, Parada LF (1991a) The trk proto-oncogene product: a signal transducing receptor for nerve growth factor. Science 252:554-558.

Kaplan DR, Martin ZD, Parada LF (1991b) Tyrosine phosphorylation and tyrosine kinase activity of the trk proto-oncogene product induced by NGF. Nature 350:158-160.

Klein R, Jing SQ, Nanduri V, O'Rourke E, Barbacid M (1991) The trk proto-oncogene encodes a receptor for nerve growth factor. Cell 65 : 189-197.

Koener TJ, Hill JE, Myers AM, Tzagolorr A (1991) High expression vectors with multiple cloning sites for construction of $\operatorname{trp} \mathrm{E}$ fusion genes: pATH vectors. Methods Enzymol 194:477-490.

Koizumi S, Contreras ML, Matsuda Y, Hama T, Lazarovici P, Guroff G (1988) K-252a: a specific inhibitor of the action of nerve growth factor on PC 12 cells. J Neurosci 8:715-721.

Laemmli UK (1970) Cleavage of structural proteins during the assembly of the head of bacteriophage T4. Nature 227:680-685.

Levi-Montalcini R (1987) The nerve growth factor 35 years later. Science 237:1154-1162. 
Lindenbaum MH, Carbonetto S, Grosveld F, Flavell D, Mushynski WE (1988) Transcriptional and posttranscriptional effects of nerve growth factor on expression of the three neurofilament subunits in PC-12 cells. J Biol Chem 263:5662-5667.

Lindner J, Rathjen FG, Schachner M (1983) LI mono- and polyclonal antibodies modify cell migration in early postnatal mouse cerebellum. Nature 305:427-430.

Loeb DM, Maragos J, Martin ZD, Chao MV, Parada LF, Greene LA (1991) The trk proto-oncogene rescues NGF responsiveness in mutant NGF-nonresponsive PC12 cell lines. Cell 66:961-966.

Mann DA, Doherty P, Walsh FS (1989) Increased intracellular cyclic AMP differentially modulates nerve growth factor induction of three neuronal recognition molecules involved in neurite outgrowth. J Neurochem 53:1581-1588.

Martini R, Schachner M (1988) Immunoelectron microscopic localization of neural cell adhesion molecules (L1, N-CAM, and myelinassociated glycoprotein) in regenerating adult mouse sciatic nerve. J Cell Biol 106:1735-1746.

McGuire JC, Greene LA, Furano AV (1978) NGF stimulates incorporation of fucose or glucosamine into an external glycoprotein in cultured rat PC12 pheochromocytoma cells. Cell 15:357-365.

Miura M, Kobayashi M, Asou H, Uyemura K (1991) Molecular cloning of cDNA encoding the rat neural cell adhesion molecule L1. Two L1 isoforms in the cytoplasmic region are produced by differential splicing. FEBS Lett 289:91-95.

Moos M, Tacke R, Scherer H, Teplow D, Fruh K, Schachner M (1988) Neural adhesion molecule L1 as a member of the immunoglobulin superfamily with binding domains similar to fibronectin. Nature 334: 701-703.

Prentice HM, Moore SE, Dickson JG, Doherty P, Walsh FS (1987) Nerve growth factor-induced changes in neural cell adhesion molecule (N-CAM) in PC12 cells. EMBO J 6:1859-1863.

Prince JT, Alberti L, Healy PA, Nauman SJ, Stallcup WB (1991) Molecular cloning of NILE glycoprotein and evidence for its continued expression in mature rat CNS. J Neurosci Res 30:567-581.
Radeke MJ, Misko TP, Hsu C, Herzenberg LA, Shooter EM (1987) Gene transfer and molecular cloning of the rat nerve growth factor receptor. Nature 325:593-597.

Rathjen FG, Schachner M (1984) Immunocytological and biochemical characterization of a new neuronal cell surface component (L1 antigen) which is involved in cell adhesion. EMBO J 3:1-10.

Roubin R, Deagostini BH, Hirsch MR, Goridis C (1990) Modulation of NCAM expression by transforming growth factor-beta, serum, and autocrine factors. J Cell Biol 111:673-684.

Rydel RE, Greene LA (1987) Acidic and basic fibroblast growth factors promote stable neurite outgrowth and neuronal differentiation in cultures of PC12 cells. J Neurosci 7:3639-3653.

Sajovic P, Ennulat DJ, Shelanski ML, Greene LA (1987) Isolation of NILE glycoprotein-related cDNA probes. J Neurochem 49:756-763.

Schachner M, Antonicek H, Fahrig T, Faissner A, Fischer G, Kunemund V, Martini R, Meyer A, Persohn E, Pollerberg E, Probstmeimer R, Sadoul K, Sadoul R, Seilheimer B, Thor G (1989) Families of neural cell adhesion molecules. In: Morphoregulatory molecules (Edelman GM, Cunningham BA, Thiery JP, eds), pp 443-468. New York: Wiley.

Seilheimer B, Schachner M (1987) Regulation of neural cell adhesion molecule expression on cultured mouse Schwann cells by nerve growth factor. EMBO J 6:1611-1616.

Stallcup WB, Beasley L (1985) Involvement of the nerve growth factor-inducible large external glycoprotein (NILE) in neurite fasciculation in primary cultures of rat brain. Proc Natl Acad Sci USA 82: $1276-1280$.

Verdi, JM, Birren SJ, Ibanez CF, Persson H, Kaplan DR, Benedetti M, Chao MV, Anderson DJ (1994) p75 ${ }^{\text {LNGFR }}$ regulates Trk signal transduction and NGF-induced neuronal differentiation in MAH cells. Neuron 12:733-745.

von Bohlen und Halbach F, Taylor J, Schachner M (1992) Cell typespecific effects of the neural adhesion molecules L1 and N-CAM on diverse second messenger systems. Eur J Neurosci 4:896-909. 